\title{
定点観測に基づく名古屋市堀川を遡上する海風と風の道としての効果 に関する研究

\author{
SEA BREEZES BLEW UP ALONG THE HORIKAWA CANAL IN NAGOYA BASED \\ ON THE FIELD OBSERVATIONS AT FIXED POINTS AND ITS APPLICATION \\ TO WIND BLOW TRAIL DESIGN
}

\author{
橋本 剛*, 堀越哲美** \\ Tsuyoshi HASHIMOTO and Tetsumi HORIKOSHI
}

\begin{abstract}
The objective of this study is to clarify the effect of the sea breeze blowing over the Horikawa Canal on the urban climate in Nagoya. In summer of 2004, climatic conditions were observed at 10 fixed points along the canal. On July 23 and 26, the sea breeze was observed along the Horikawa Canal up to $9 \mathrm{~km}$ from the sea. Two kinds of blowing-up sea breeze were observed. On July 23, it takes about 4 or 5 hours that sea breeze blew up along the canal to the north area of the city. At that time, it takes about 1 hour that the sea breeze blew up to the north area of the city in the sky. On July 26, it takes about 2 hours that the sea breeze blew up along the canal to the center of the city. At that time, it takes about 3 hours that the sea breeze blew up to the north area of the city in the sky. Each breeze affects the different effect of the sea breeze on the heat island in Nagoya.
\end{abstract}

Keywords : Sea breeze, Canal, Heat island, Wind direction, Wind velocity, Air temperature 海風，運河，ヒートアイランド，風向，風速，気温

\section{1.はじめに}

近年、都市におけるヒートアイランドの緩和策として、海風が相 対的に冷涼な海上の空気を市街地へともたらすことによる都市の暑 熱環境を緩和する効果や、都市内に形成された連続的なオープン空 間である河川の「風の道」としての働きが着目されており、社会的 関心も高まってきている。そして、都市内河川を対象とした気候観 測調査がこれまでに東京 ${ }^{1)} 、$ 名古屋2）3）4）5）、福岡6)、広島7）8）9） 10）11）12）などの諸都市で行われ、河川の熱的効果や「風の道」とし ての働きについて検証されてきている。一般に、気候観測調査では 同時多点観測を行うのが理想的であると考えられるが、海風遡上の ような広域的な気候環境の把握を目的とする実測調査では、測定機 器や測定者の数と観測点数との関係により自動車や徒歩等による移

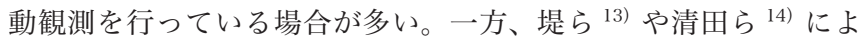
る報告等が示すように、気象台や AMeDAS 等、公共的な観測所に よる観測デー夕の活用は、都市上空における海風遡上の実態把握を 行う上で有効であると考えられる。

本研究では、先行研究によって海風遡上の影響が認められている 河川の中から名古屋市中心部を流れる運河である堀川に着目した。 前述のような現状を踏まえ、生活域である地上付近において運河を 遡上する海風の実態をより詳細に把握することを目的として、夏季 に連続的な同時多点観測を行った。また、堀川に近接して設けられ
た公共的な観測所（名古屋市の大気污染常時監視測定局）のデー夕 から、堀川流域の上空における海風遡上の実態を調査した。そして、 地上付近の海風遡上と上空における海風遡上との関係が都市気候形 成に及ぼす影響、すなわち、海風による相対的に冷涼な海上の空気 の都心部への移流が都市の気温分布形成に及ぼす影響について検討 した。

\section{2. 研究の概要}

本研究では、研究対象として名古屋市堀川を選定した。堀川を遡 上する海風のより詳細な実態把握のために堀川沿いでの定点観測を 行うとともに、堀川流域の上空における海風遡上も併せて捉えるた めに名古屋市が管理する大気污染常時監視測定局のデー夕を用いて 解析を行った。

\section{1 堀川沿いにおける定点観測の概要}

堀川沿いにおける定点観測の観測日時及び観測日の天候を表 1 に 示す。観測は 2004 年の 7 月に 4 日間行った。観測対象地域及び観 測点を図 1 に示す。観測対象河川は名古屋市中心部を流域の一部と する堀川とした。堀川沿いに 10 か所の定点を設け、9 時から 19 時まで 15 分間隔で観測を行った。観測点は、基本的には橋上の河 川中央下流側とした。ただし、観測点 1 及び 3 については、突堤状 の河川に張り出した空間に観測点を設けた。全観測点において、ア
* 筑波大学大学院人間総合科学研究科 講師 ·博士 (工学)

** 名古屋工業大学大学院工学研究科 教授·工博
Assis. Prof., Graduate School of Comprehensive Human Sciences, Univ. of Tsukuba, Dr. Eng. Prof., Graduate School of Engineering, Nagoya Institute of Technology, Dr. Eng. 
スマン通風乾湿計を三脚にて地上高さ約 $90 \mathrm{~cm}$ に固定して気温及 び湿度を、ビラム式風向風速計を三脚にて地上高さ約 $120 \mathrm{~cm}$ に固 定して風向及び風速を観測した。風向及び風速については、3 分間 の主風向及び平均風速を観測した。観測点 1 及び 3 において、日射

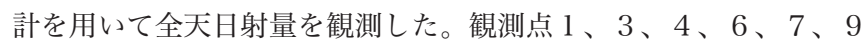
及び 10 において、放射温度計を用いて水表面温度及び地表面温度 を観測した。ただし、7月 23 日の観測では、観測点 8 及び 9 の 2 点を 1 組の観測者が 30 分ごとに移動して観測を行った。すなわち、 毎時 0 分と 45 分には観測点 8 で、毎時 15 分と 30 分には観測点 9 で観測を行った。また、7月 23 日の観測では観測点 9 における水 表面温度及び地表面温度の観測を行っていない。

7 月 23 日及び 26 日には太平洋高気圧が東海地方を広く覆って いた。7月 28 日には名古屋市付近は太平洋高気圧に覆われていた が、台風 10 号が八丈島の南東海上をゆっくりとした速さで西進し ていた。7月 30 日には台風 10 号が東海地域の南海上においてゆっ くりとした速さで西進し、台風の北端が名古屋市付近を掠めた。

\section{2 公共的な観測所における観測データの解析}

図 1 に示した観測点 $\mathrm{A}$ 及びBが解析対象の観測所である。これら は名古屋市の管理する大気污染常時監視測定局であり、風向及び風

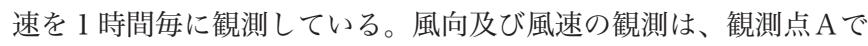
は 2002 年 3 月から、観測点 B では 2003 年 3 月から行っている。 海風が最も発達すると考えられる夏季として各年の梅雨明けから 8 月 31 日までを調査対象期間とし、2003 年から 2006 年の 4 年間 の観測結果について解析を行った。本研究では以下の（1）〜 (4) の条件を全て満たす風向及び風速の変化が観測された日を標準的な 海風発達日として仮定し、観測点 $\mathrm{A}$ 及び $\mathrm{B}$ における海風吹走開始時

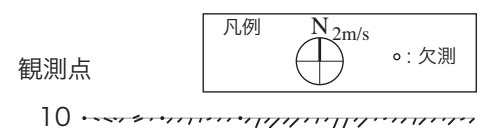

10 .

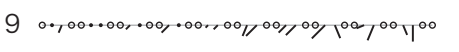

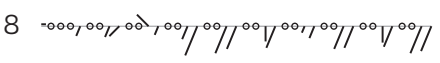

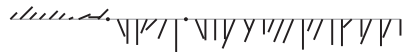

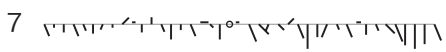

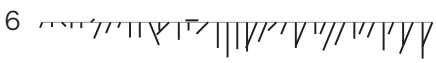

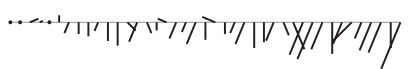

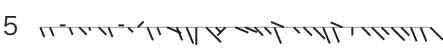

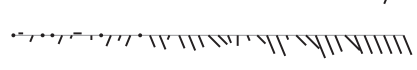

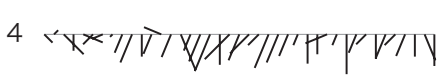

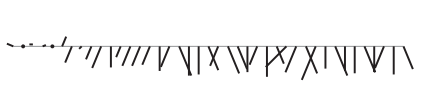

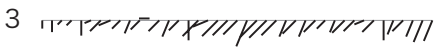

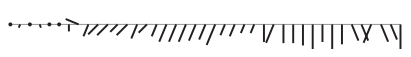

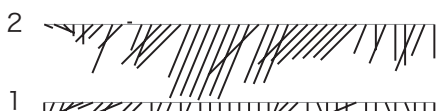
u1

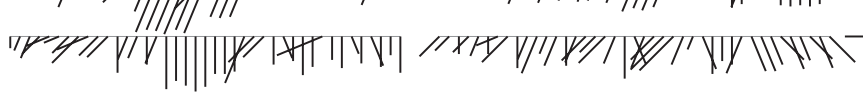

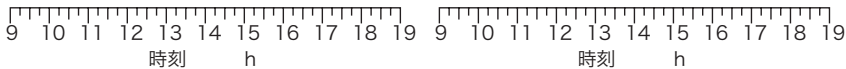
2004年7月23日

2004年7月26日
表 1 観測日時及び観測日の天候

\begin{tabular}{ccc}
\hline 観測日 & 観測時間 & 天候 \\
\hline \hline 2004 年 7 23 & $9: 00 \sim 19: 00$ & 晴れ \\
2004 年 7 26 日 & $9: 00 \sim 19: 00$ & 曇り \\
2004 年 7 月 28 日 & $9: 00 \sim 19: 00$ & 晴れのち量り \\
2004 年 7 月 30日 & $9: 00 \sim 19: 00$ & 量り一時雨 \\
\hline
\end{tabular}

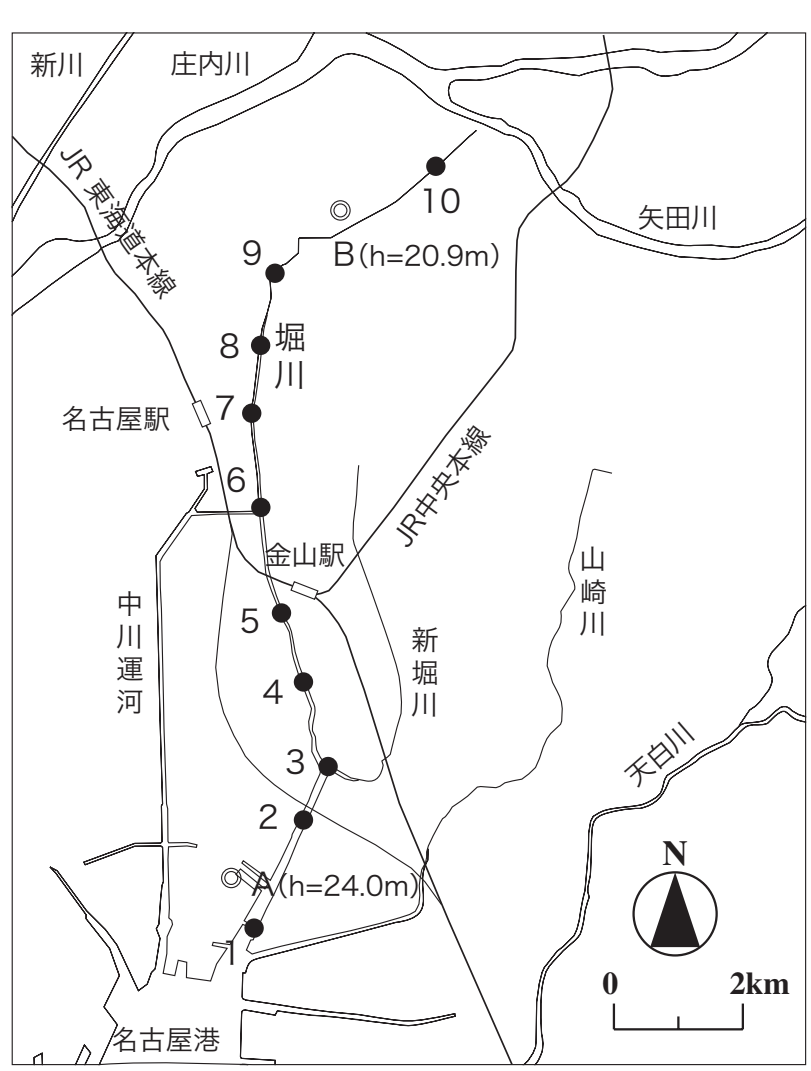

図 1 観測対象地域及び観測点
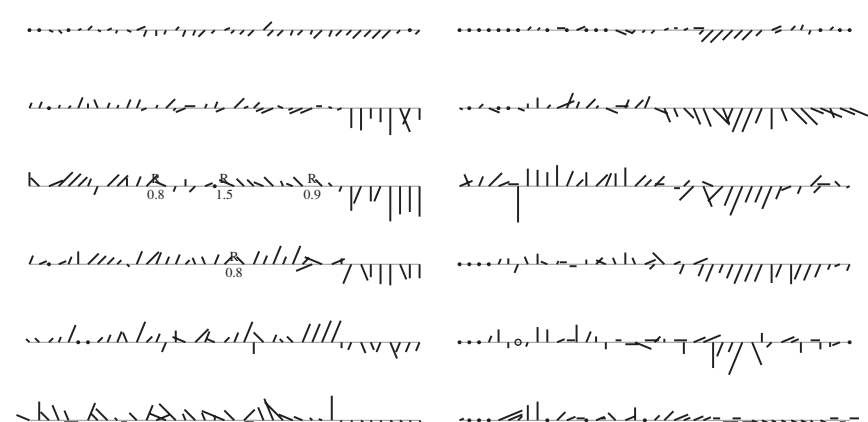

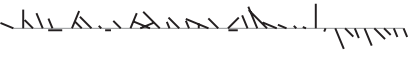

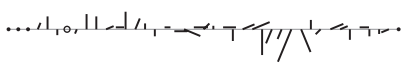

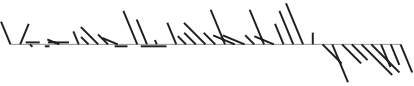

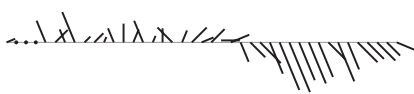

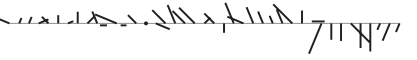
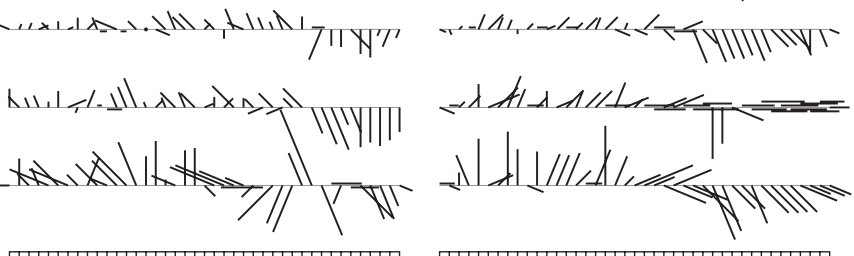

時刻 $\mathrm{h}$

2004年7月28日
2004年7月30日

図2 全観測日における風向・風速の観測結果 
刻を求めた。

[本研究で仮定した標準的な海風発達日の風向・風速条件］

（1）風向が南より（南西、南南西、南、南南東、南東）かつ風速 $1 \mathrm{~m} / \mathrm{s}$ 以上の風を海風の可能性がある海よりの風とする。

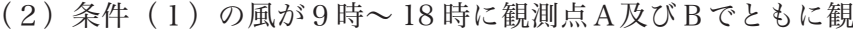
測され始め、その後 3 時間以上連続して観測される。

（3）条件（1）の風が観測され始めるのは海に近い観測点 $\mathrm{A} の$ 方 が早い、または観測点 $\mathrm{A}$ と B で同じ観測時刻である。

（4）台風、低気圧等、明らかに海風循環の形成以外の気象的要因 が影響している場合は除外する。

\section{3．堀川沿いにおける定点観測の結果}

全観測日における全観測点での風向風速の観測結果を図 2 に示 す。 7 月 23 日及び 26 日には、南よりの風の発達が日中から夕方 にかけて観測された。 7 月 28 日及び 30 日には夕方 16 時頃以降に 南から南東よりの風が観測された。全観測日における観測点 1 での 気温の観測結果を図 3 に示す。 7 月 23 日及び 26 日には、日中に おける気温上昇が抑えられている。この両日は、日中に強い南風の 発達が観測された。一例として、7月 23 日の各観測点における気 温及び日射量の観測結果を図 4 及び図 5 に示す。12 時頃から 17 時 頃の気温変動をみると、観測点 $1 、 2 、 3$ では 12 時以降に気温が 低下しており、15 時以降に再び上昇した。観測点 4、5、6では 12 時以降の気温上昇が抑えられており、観測点 5 では気温変動が みられるものの、12 時頃から 17 時頃まではほぼ一定の気温で推移 した。このような昼間の気温上昇が抑えられ南よりの風が発達する 現象は、7月 26 日も同様であった。また、観測点 5 及び 7 は他の 観測点に比べ相対的に気温が高くなることが多かった。

7 月 23 日の各観測点における水表面温度の観測結果を図 6 に示 す。水表面温度は観測時間を通して $24 \sim 32^{\circ} \mathrm{C}$ の間で推移した。観 測点 1 の全観測時間及び観測点 7 の 14 時以降を除き、各観測点て の水表面温度は変動が大きかった。

\section{4. 堀川沿いにおける定点観測結果の考察}

7 月 23 日及び 26 日の日中には、河口から上流にわたり強い南 よりの風の発達が認められる（図 2 )。これは海風の発達を示すも のであると考えられる。そして、海風が発達した両日には日中にお ける気温上昇が抑えられており、観測点 $1 、 2 、 3$ では 12 時以降 に気温低下の始まることが認められる（図 3 ・図 4 ・図 5 )。これは、 海風による都市の暑熱環境を緩和する効果が気温変動に顕著に現れ ているものと考えられる。そして、その効果は河口に近い観測点に おいてより強く現れることが示された。

次に、地上付近における海風遡上の様子をより視覚的に把握する ことを試みる。日中における典型的な海風の発達が認められた 7 月 23 日及び 26 日について、風向が南より（南西、南南西、南、南南東、 南東）の観測結果から、風速 $2 \mathrm{~m} / \mathrm{s}$ 以上及び風速 $1 \mathrm{~m} / \mathrm{s}$ 以上 $2 \mathrm{~m} / \mathrm{s}$ 未満のものを抽出し、それぞれ「○」と「○」の記号で示した結果 を表 2 に示す。表 2 から、 7 月 23 日には 9 時 30 分頃に海風が堀 川を遡上し始め、14 時頃に最も上流の観測点 10 にまで海風が遡上 したものと推察される。一方、 7 月 26 日には 10 時頃から海風が 堀川を遡上し始め、11 時 45 分頃に観測点 8 まで海風が遡上し、そ

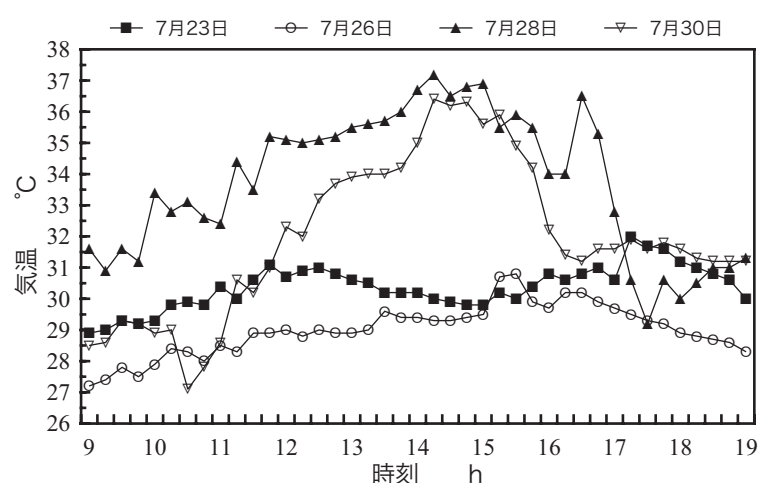

図３＼cjkstart全観測日における観測点 1 での気温の観測結果

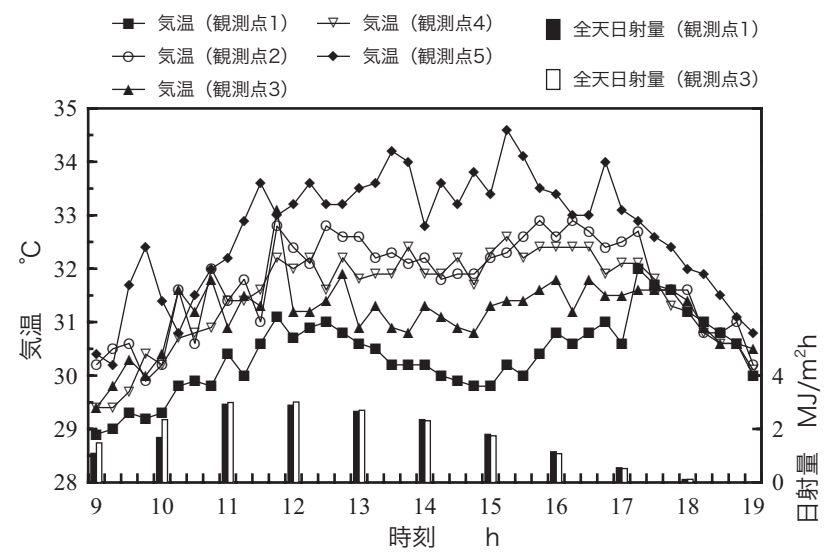

図47月 23 日の気温の観測結果（観測点 $1 \sim 5$ )

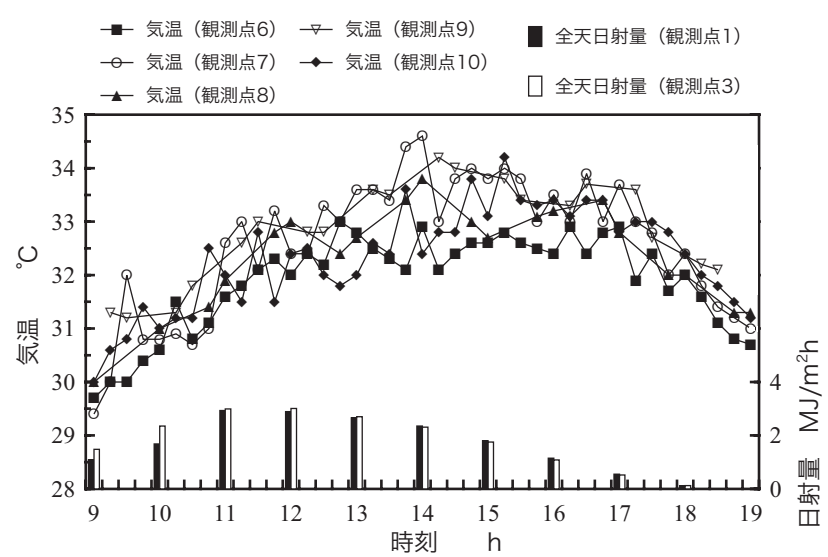

図 57 月 23 日の気温の観測結果（観測点 6〜 10)

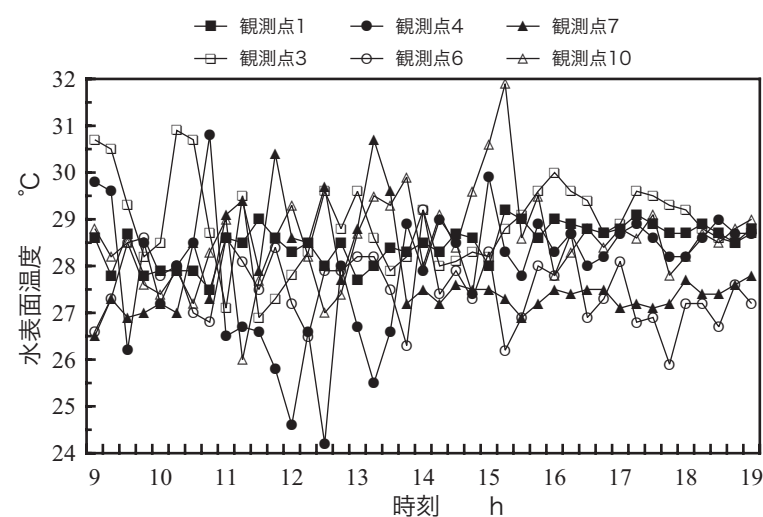

図 67 月 23 日の水表面温度の観測結果 
の後 14 時 45 分頃に観測点 9 まで海風が遡 上したものと推察される。このように、両日 の運河沿いにおける海風遡上の様子には、遡 上距離や遡上に要する時間に明確な違いが認

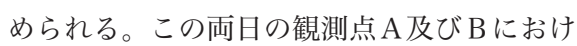
る上空風の風向及び風速の観測結果を図 7 及 び図 8 に示す。 7 月 23 日（図 7 ）には、河 口付近 (観測点 $\mathrm{A}) 、$ 名古屋市北部（観測点 B）ともに 10 時より海風が観測された。一 方、7月26日（図8）には、河口付近（観 測点A）で 9 時に海風が観測され始め、その 3 時間後の 12 時に名古屋市北部（観測点 B ) でも海風が観測され始めた。すなわち、今回 の観測では、1) 市街地上空では河口付近（観 測点 A) で海風が観測された後 1 時間以内に 名古屋市北部（観測点 B ）でも海風が観測さ れ、地上付近では河口付近（観測点 1 ）で海 風が観測された後約 4〜5時間かけて名古 屋市北部（観測点 10）まで海風が遡上する 場合 [ケース 1：7月 23日）と、2）市街 地上空では河口付近（観測点 $\mathrm{A}$ ）で海風が観 測された約 3 時間後に名古屋市北部（観測点 B ）でも海風が観測され、地上付近では河口 付近（観測点 1 ）で海風が観測された後約 2 時間程度で名古屋市都心部（観測点 8 ）まで 遡上する場合 [ケース 2：7月 26 日］、と

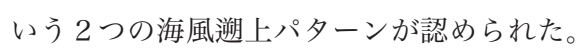

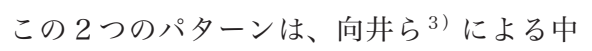
川運河での観測でもみられている。また、海 風がすでに到達したと考えられる時間帯でも 海風が明確に観測されていない場合も認めら れる。これは、堀川の川幅が中流から上流に かけての市街地中心部では約 $17 〜 20 \mathrm{~m}$ と 比較的狭く、建物の建て込从具合も変化する

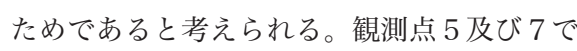
はそれより上流の観測点よりも風速が弱くな ることが多い。両観測点での気温が高い（図 4・図 5 ）ことと併せて考えると、これは、 観測点 7 が名古屋市都心部（伏見）に、観 測点 5 が名古屋市副都心部（金山）に位置するため、周辺の都市と しての集積度の高さによる環境への影響が気温上昇や風速低下とし て現れているものと考えられる。集積度の低減や蒸散効果を考慮し、 オープン空間を設ける、沿道の緑化をする等、河川周辺を「風の道」 として整備することにより、名古屋市都心部へ海風を導くことがで きる可能性の高いことが示唆された。

7 月 23 日及び 26 日における、観測点 1 からの距離と気温の関 係を図 9 及び図 10 にそれぞれ示す。 7 月 23 日（ケース 1 : 図 9) では、海風が上流まで遡上した直後と考えられる 14 時やその 2 時 間後の 16 時には海風による暑熱環境を緩和する効果が現れ、海か らの距離が遠くなるほど気温が上昇する傾向が認められる。これに
表2 風向及び風速の観測結果の場合分け（7月 23 日・26日）

\begin{tabular}{|c|c|c|c|c|c|c|c|c|c|c|c|c|c|c|c|c|c|c|c|c|c|}
\hline \multicolumn{11}{|c|}{2004 年 7 月 23 日 } & \multicolumn{11}{|c|}{2004 年 7 月 26 日 } \\
\hline \multirow{2}{*}{ 観測時刻 } & \multicolumn{10}{|c|}{ 観測点 } & \multirow{2}{*}{ 観測時刻 } & \multicolumn{10}{|c|}{ 観測点 } \\
\hline & 1 & 2 & 3 & 4 & 5 & 6 & 7 & 8 & 9 & 10 & & 1 & 2 & 3 & 4 & 5 & 6 & 7 & 8 & 9 & 10 \\
\hline 9:00 & 0 & & & 0 & & & 0 & & - & & 9:00 & 0 & & & & & & & & & \\
\hline $9: 15$ & 0 & & O & & & & & - & & & $9: 15$ & 0 & & & & & & & & & \\
\hline $9: 30$ & 0 & & & 0 & & & & - & & & $9: 30$ & 0 & & & & & & & & 0 & \\
\hline $9: 45$ & 0 & 0 & & & & & 0 & - & - & & $9: 45$ & 0 & & & & & & & & & \\
\hline 10:00 & & 0 & $\mathrm{O}$ & & & & & & - & & 10:00 & 0 & & & & & & & & & \\
\hline $10: 15$ & & 0 & & 0 & & & & - & & & 10:15 & 0 & 0 & & & & & & & & \\
\hline $10: 30$ & 0 & 0 & $\mathrm{O}$ & & & 0 & & - & & & $10: 30$ & & 0 & & 0 & & 0 & & & & \\
\hline $10: 45$ & 0 & 0 & & & & 0 & & 0 & - & & $10: 45$ & 0 & 0 & & & & 0 & & & 0 & \\
\hline $11: 00$ & & 0 & $\mathrm{O}$ & O & & & & O & - & & $11: 00$ & 0 & 0 & 0 & O & & 0 & & & & \\
\hline $11: 15$ & 0 & 0 & $\mathrm{O}$ & 0 & & 0 & & - & & & $11: 15$ & 0 & 0 & 0 & 0 & & & & & & \\
\hline $11: 30$ & 0 & 0 & $\mathrm{O}$ & 0 & & 0 & & - & & & $11: 30$ & 0 & 0 & 0 & 0 & 0 & 0 & & & 0 & \\
\hline $11: 45$ & 0 & 0 & & O & 0 & 0 & & & - & & $11: 45$ & 0 & 0 & & 0 & & 0 & & 0 & & \\
\hline $12: 00$ & 0 & 0 & O & & & & & & - & & 12:00 & 0 & 0 & 0 & 0 & 0 & 0 & 0 & 0 & & \\
\hline $12: 15$ & 0 & 0 & $\mathrm{O}$ & 0 & & 0 & 0 & - & & & $12: 15$ & 0 & 0 & 0 & 0 & & 0 & & 0 & 0 & \\
\hline $12: 30$ & 0 & 0 & $\mathrm{O}$ & 0 & 0 & 0 & & - & & & $12: 30$ & 0 & 0 & 0 & 0 & 0 & 0 & & O & 0 & \\
\hline $12: 45$ & 0 & 0 & $\mathrm{O}$ & 0 & 0 & & 0 & $\mathrm{O}$ & - & & $12: 45$ & 0 & 0 & 0 & 0 & 0 & & & 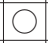 & & \\
\hline 13:00 & 0 & 0 & $\mathrm{O}$ & 0 & 0 & & & 0 & - & & 13:00 & 0 & 0 & 0 & 0 & & & O & O & & \\
\hline 13:15 & 0 & 0 & & 0 & 0 & 0 & & - & & & 13:15 & 0 & 0 & 0 & 0 & 0 & 0 & & 0 & & \\
\hline 13:30 & 0 & 0 & O & 0 & & 0 & O & - & & & 13:30 & 0 & 0 & 0 & 0 & 0 & & & & & \\
\hline $13: 45$ & 0 & 0 & 0 & 0 & O & 0 & & 0 & - & & $13: 45$ & 0 & 0 & 0 & 0 & 0 & 0 & 0 & 0 & & \\
\hline $14: 00$ & 0 & 0 & O & 0 & & 0 & & 0 & - & 0 & $14: 00$ & 0 & 0 & 0 & 0 & 0 & 0 & & O & & \\
\hline $14: 15$ & 0 & 0 & $\mathrm{C}$ & 0 & & 0 & O & - & 0 & & $14: 15$ & 0 & 0 & 0 & 0 & 0 & & 0 & O & & \\
\hline $14: 30$ & 0 & 0 & O & 0 & 0 & 0 & 0 & - & $O$ & 0 & $14: 30$ & 0 & 0 & 0 & 0 & & 0 & & 0 & & \\
\hline $14: 45$ & 0 & 0 & 0 & 0 & & 0 & & 0 & - & & $14: 45$ & 0 & 0 & 0 & 0 & & 0 & & 0 & 0 & \\
\hline $15: 00$ & 0 & 0 & $\mathrm{O}$ & 0 & 0 & 0 & & 0 & - & & 15:00 & 0 & 0 & & 0 & & 0 & & O & & \\
\hline 15:15 & 0 & 0 & 0 & 0 & & 0 & & - & & & $15: 15$ & 0 & 0 & & 0 & 0 & 0 & & 0 & 0 & \\
\hline $15: 30$ & 0 & 0 & $\mathrm{O}$ & 0 & & 0 & 0 & - & $O$ & 0 & 15:30 & 0 & 0 & 0 & 0 & 0 & 0 & & 0 & 0 & \\
\hline $15: 45$ & 0 & 0 & $\mathrm{O}$ & 0 & 0 & 0 & 0 & & - & 0 & $15: 45$ & 0 & 0 & 0 & 0 & 0 & 0 & 0 & 0 & 0 & \\
\hline 16:00 & 0 & 0 & $\mathrm{O}$ & 0 & 0 & 0 & 0 & 0 & - & & 16:00 & 0 & 0 & 0 & 0 & & 0 & & 0 & 0 & \\
\hline $16: 15$ & 0 & 0 & 0 & & 0 & 0 & 0 & - & 0 & 0 & $16: 15$ & 0 & 0 & 0 & 0 & 0 & 0 & 0 & 0 & 0 & \\
\hline 16:30 & 0 & 0 & 0 & 0 & 0 & 0 & & - & 0 & & $16: 30$ & 0 & 0 & 0 & 0 & 0 & 0 & $O$ & 0 & 0 & \\
\hline $16: 45$ & 0 & 0 & 0 & 0 & & 0 & 0 & 0 & - & & $16: 45$ & 0 & 0 & 0 & 0 & 0 & 0 & 0 & 0 & 0 & \\
\hline 17:00 & 0 & 0 & $\mathrm{O}$ & 0 & & 0 & & 0 & - & & $17: 00$ & 0 & 0 & 0 & 0 & 0 & 0 & O & 0 & & \\
\hline $17: 15$ & 0 & 0 & & 0 & 0 & 0 & & - & & & $17: 15$ & 0 & 0 & 0 & 0 & 0 & 0 & 0 & 0 & 0 & \\
\hline $17: 30$ & 0 & 0 & $\mathrm{O}$ & 0 & 0 & 0 & & - & 0 & & $17: 30$ & 0 & 0 & 0 & 0 & 0 & 0 & 0 & 0 & 0 & \\
\hline $17: 45$ & 0 & 0 & 0 & 0 & & 0 & 0 & 0 & - & & $17: 45$ & 0 & 0 & 0 & 0 & 0 & 0 & $\bigcirc$ & 0 & 0 & \\
\hline 18:00 & 0 & 0 & 0 & 0 & 0 & 0 & 0 & 0 & - & & 18:00 & 0 & 0 & 0 & 0 & 0 & 0 & 0 & O & O & \\
\hline 18:15 & 0 & 0 & 0 & 0 & 0 & 0 & 0 & - & & & $18: 15$ & 0 & 0 & 0 & 0 & 0 & 0 & 0 & 0 & 0 & \\
\hline 18:30 & 0 & 0 & $\mathrm{O}$ & 0 & 0 & 0 & 0 & - & 0 & & 18:30 & 0 & 0 & 0 & 0 & 0 & 0 & 0 & 0 & 0 & \\
\hline $18: 45$ & 0 & 0 & 0 & 0 & 0 & 0 & 0 & 0 & - & & $18: 45$ & 0 & 0 & 0 & 0 & 0 & 0 & 0 & $O$ & & \\
\hline 19:00 & 0 & 0 & $\mathrm{O}$ & 0 & 0 & 0 & 0 & 응 & - & & 19:00 & 0 & 0 & 0 & 0 & 0 & 0 & & 0 & 0 & \\
\hline
\end{tabular}

対し 7 月 26 日（ケース $2:$ 図 10）の気温分布をみると、海風が遡 上途中であると考えられる 11 時や海風が都心部まで到達した直後 と考えられる 12 時には、観測点 8 までは海風による暑熱環境を緩 和する効果が現れ気温がほぼ一定となっており、海風が十分到達し ていない観測点 9 が高温となっている。そして、海風が都心部まで 到達した後に約 2 時間経過したと考えられる 15 時には、観測点 9 での気温低下が伺える。海風が最も発達したと考えられる時間帯 $(7$ 月 23 日の 14 時〜 16 時、 7 月 26 日の 12 時〜 14 時）と日中に海 風が吹走しなかった時間帯（ 7 月 28 • 30 日の 13 時〜 15 時）に おける、観測点 1 を基準とした気温差の平均値の分布を図 11 に示 す。観測対象地域内の気温差は、7月23日（ケース 1）では平均 


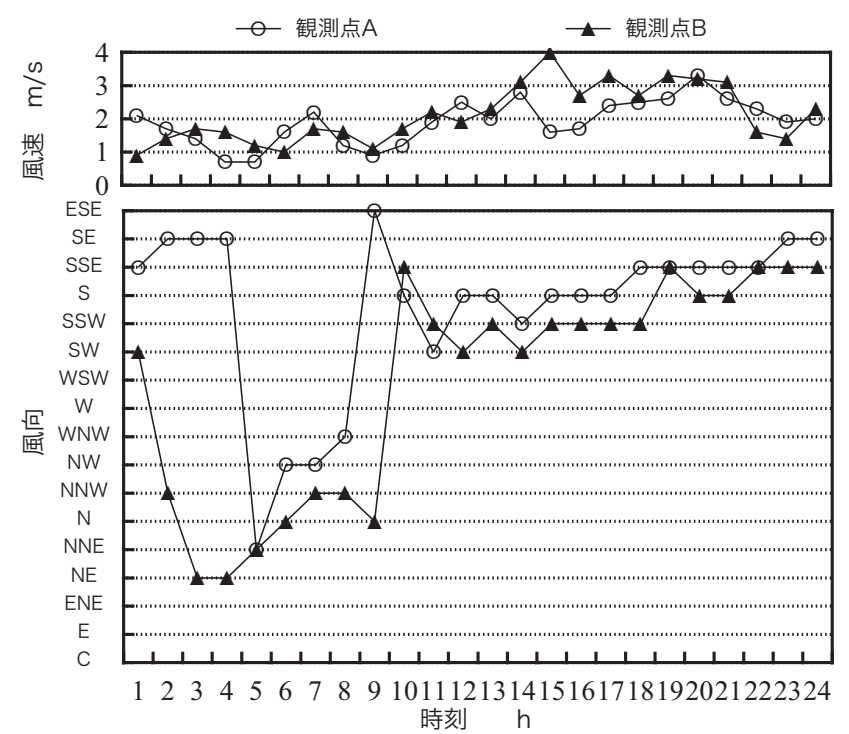

図 7 上空風の観測結果 $(7$ 月 23 日)

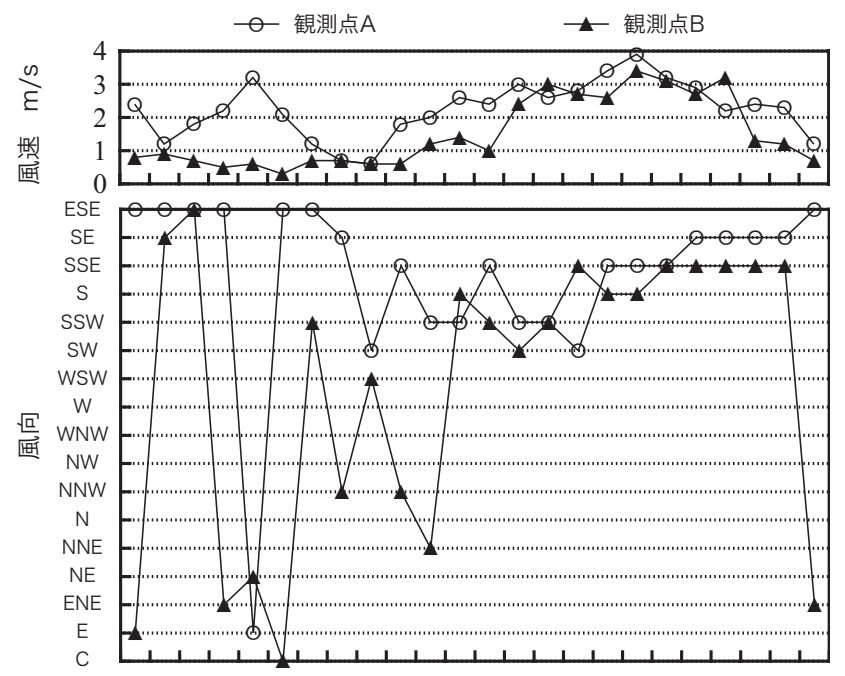

123456789101112131415161718192021222324 時刻 $h$

図 8 上空風の観測結果 $(7$ 月 26 日 $)$

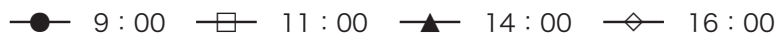

$\begin{array}{llllllllll}\text { 観測点 } & 1 & 2 & 3 & 4 & 5 & 6 & 7 & 8 & 10\end{array}$

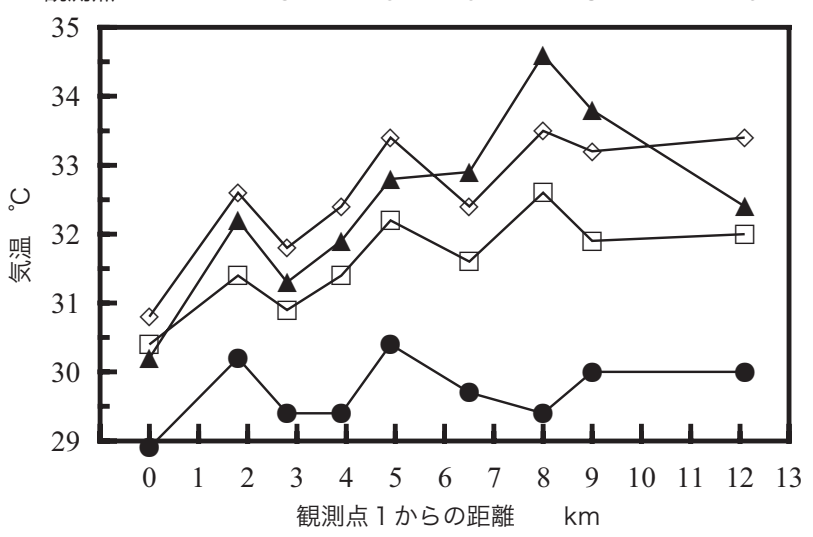

図 9 観測点 1 からの距離と気温の関係（7月 23 日）

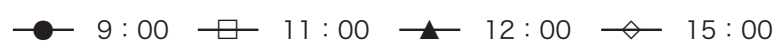

$\begin{array}{lllllllllll}\text { 観測点 } & 1 & 2 & 3 & 4 & 5 & 6 & 7 & 8 & 9 & 10\end{array}$

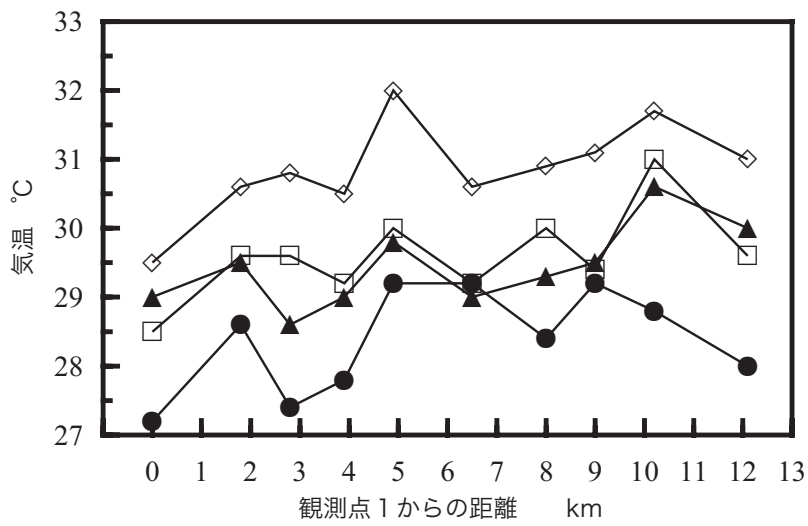

図 10 観測点 1 からの距離と気温の関係（7月 26 日）

一— 7月23日(14:00～16:00の平均)

一一 7月26日(12:00 14:00の平均)

$\triangle 7$ 月28·30日(13:00 15:00の平均)

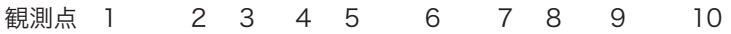

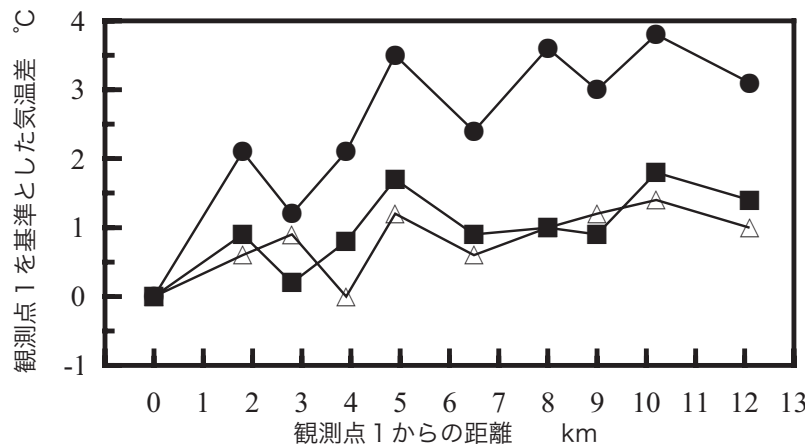

図 11 観測点 1 からの距離と、観測点 1 を基準とした時の 気温差の平均値との関係

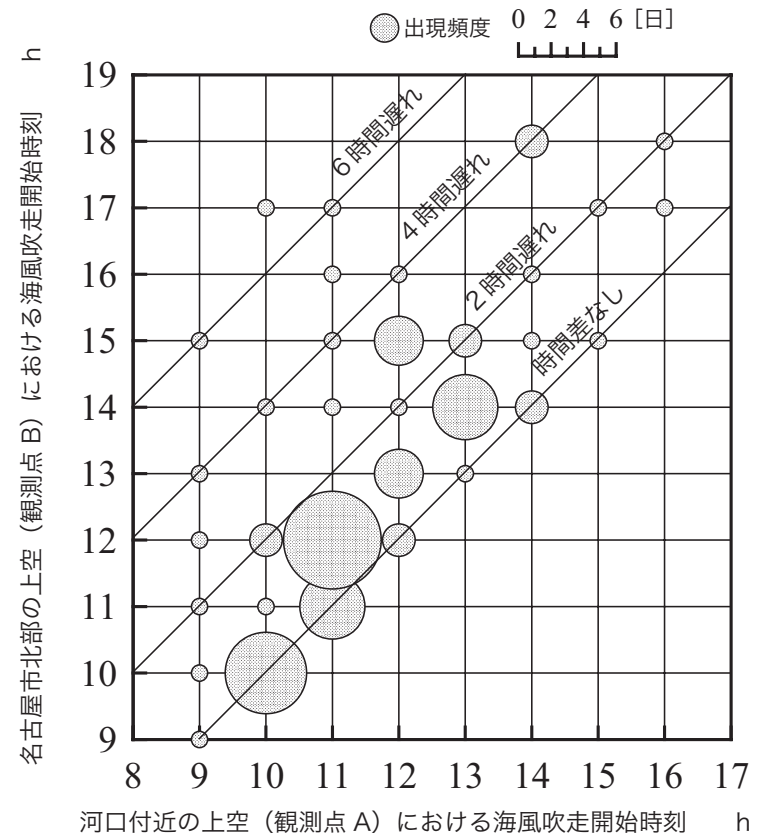

図 12 上空における海風吹走開始時刻 
で最大約 $4{ }^{\circ} \mathrm{C}$ 程度であるのに対し、7月 26 日（ケース 2) では平 均で最大約 $2{ }^{\circ} \mathrm{C}$ 程度である。海風遡上パターンの違いにより河川沿 いに形成される気温分布への影響が異なると考えられる。一方、海 風が吹走しなかった時には平均で最大約 $1.5^{\circ} \mathrm{C}$ 程度の気温差が認め られる。これはヒートアイランドの出現を示すものであると考えら れる。

また、水表面温度は一部を除いて変動が激しかった（図 6)。こ れは、堀川は河口から $13.6 \mathrm{~km}$ 上流付近までが潮位の影響を受ける 感潮区域 ${ }^{15)}$ となっていることに加え、堀川沿いに点在する下水処 理場から放流される処理水や、最上流部における庄内川からの導水 の影響もあると推察される。

\section{5.上空における海風遡上パターン}

2.2 で示した条件に基づき、2003 年から 2006 年の夏季 (本研 究では、梅雨明けから 8 月 31 日までを対象期間とした）における 本研究で仮定した標準的な海風発達日を抽出した。標準的な海風発 達日として、4 年で計 57 日が抽出された。河口付近の上空（観測 点 $\mathrm{A}$ ）と名古屋市北部の上空（観測点 $\mathrm{B}$ ）における海風吹走開始時 刻の関係を図 12 に示す。河口付近の上空（観測点 A）に対する名 古屋市北部の上空（観測点 B ）での海風吹走開始時刻の時間遅れの 出現頻度を図 13 に示す。これらの結果から、名古屋市堀川流域の 上空における海風遡上のパターンとしては、10 時から 13 時に河口 付近で海風が観測され始め、その後約 2 時間以内に名古屋市北部で も海風が観測され始める場合 [ケース A : 短時間遡上型 $]$ が多いこ とが明らかになった。しかし、出現頻度は比較的少ないものの、河 口付近で海風が観測され始めてから 3 時間以上後に名古屋市北部で も海風が観測され始める場合 [ケース $\mathrm{B}$ ：長時間遡上型］もみられ る。堀川沿いの定点観測において日中の海風発達が認められた 7 月 23 日及び 26 日の海風遡上パターンについて考えると、23 日がケー ス Aの短時間遡上型、26 日がケース B の長時間遡上型に該当する 観測事例といえる。

\section{6. 結論}

生活域である地上付近において運河を遡上する海風のより詳細な 実態把握を目的として、2004 年の夏季に名古屋市の堀川流域を対 象とした気温、風向、風速等の定点観測を行った。また、堀川流域 における上空の海風遡上と地上付近の海風遡上との関係が都市気候 形成に及ぼす影響を明らかにするため、名古屋市の大気污染常時監 視測定局における観測デー夕の解析を行った。その結果、堀川沿い における 10 か所での定点観測と上空風の風向及び風速の経時変動 から、今回の観測では、1）上空では河口付近で海風が観測され始 めてから比較的短時間（1 時間以内）の内に名古屋市北部でも海風 が観測され始め、地上付近では海風が比較的長時間（4〜 5 時間） をかけて遡上し、地上付近では堀川上流まで海風が到達する、2) 上空では河口付近で海風が観測され始めてから比較的長時間（約 3 時間）が経った後に名古屋市北部でも海風が観測され始め、地上付 近では海風が比較的短時間（約 2 時間）で遡上し、地上付近での海 風遡上距離が比較的短い、という 2 つの海風遡上パターンが認めら れた。そして、それぞれのパターンによって運河沿いに形成される 気温分布が異なることを明らかにした。また、堀川流域上空におけ

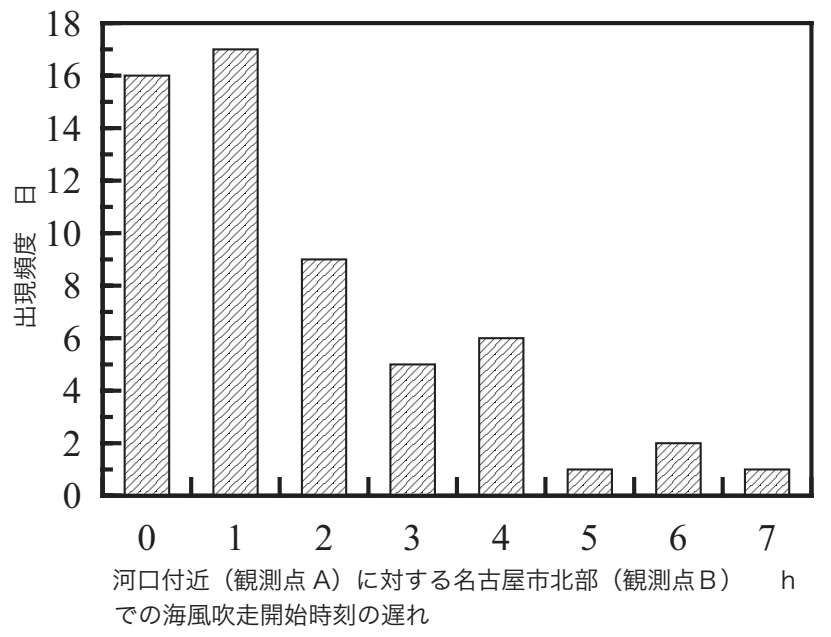

図 13 上空における海風吹走開始時刻の時間遅れ

る海風遡上のパターンとしては、10 時から 13 時に河口付近で海風 が観測され始め、その後約 2 時間以内に名古屋市北部でも海風が観 測され始める場合が比較的多くみられることを示した。一方、都市 の集積度が高い場所では相対的に気温が高く、風速が低下する傾向 もみられた。そのような地域の建築・都市デザインを「風の道」に 配慮したものへと改善することにより、名古屋市都心部における海 風の「風の道」が確保できるものと期待できる。

\section{参考文献}

1) 成田健一, 植村明子, 三坂育正 : 都市気候に及ぼす河川水の熱的影響に関 する実測研究隅田川における熱収支と周辺環境の検討, 日本建築学会計 画系論文集，第 545 号, pp.71-78, 2001.7

2 ) 橋本剛, 舩橋恭子, 堀越哲美: 海風の運河遡上による都市暑熱環境の緩和 効果 一名古屋市の堀川及び新堀川における事例-, 日本建築学会計画系 論文集，第 545 号，pp.65-70，2001.7

3 ) 向井愛, 堀越哲美: 名古屋市中川運河における海風遡上が体感気候に及ぼ す影響, 日本建築学会計画系論文集, 第 553 号, pp.37-41, 2002.3

4 ）橋本剛, 堀越哲美 : 名古屋市近郊に位置する庄内川及び新川の河川の「風 の道」としての働き, 日本建築学会環境系論文集, 第 571 号, pp.55-62, 2003.9

5 ) 橋本剛, 堀越哲美 : 庄内川及び新川を吹走する伊吹おろしが名古屋市の都 市気候形成に及ぼす影響, 日本建築学会環境系論文集, 第 592 号, pp.51-58, 2005.6

6 ）片山忠久, 石井昭夫, 西田勝, 林徹夫, 堤純一郎, 塩月義隆, 北山広樹, 高山和宏, 大黒雅之 : 海岸都市における河川の暑熱緩和効果に関する調査 研究, 日本建築学会計画系論文報告集, 第 418 号, pp.1-9, 1990.12

7 ）村川三郎, 関根毅, 成田健一, 西名大作 : 都市内河川が周辺の温熱環境に 及ぼす効果に関する研究, 日本建築学会計画系論文報告集, 第 393 号, pp.25-34, 1988.11

8 ）村川三郎, 関根毅, 成田健一, 西名大作, 千田勝也 : 都市内河川が周辺の 温熱環境に及ぼす効果に関する研究（続報）水平および鉛直的影響範囲 の検討，日本建築学会計画系論文報告集，第 415 号，pp.25-34，1990.9

9 ) 福岡義隆, 高橋日出夫, 開発一郎 : 都市気候環境の創造における水と緑の 役割, 日本生気像学会雑誌，第 29 巻 - 第 2 号, pp.101-106, 1992.8

10）清田忠志, 谷口明, 清田誠良, 中村安弘: 都市域におけるヒートアイラン ド現象の緩和方策に関する研究, 日本建築学会環境系論文集, 第 602 号, pp.69-75, 2006.4 
11）清田忠志, 谷口明, 清田誠良, 中村安弘 : 都市域におけるヒートアイラン ド現象の緩和方策に関する研究その 2 広島市の夏季の都市気温と土地 被覆との関係に対する重回帰分析, 日本建築学会環境系論文集, 第 614 号, pp.57-63, 2007.4

12）谷口明，清田誠良，清田忠志：沿岸都市における海風が有する都市域の高 温化現象の緩和効果に関する研究, 日本建築学会環境系論文集, 第 625 号, pp.379-384, 2008.3
13）堤純一郎，片山忠久，石井昭夫，西田勝，北山広樹：夏季の海陸風を対象 とする気象デー夕の統計解析, 日本建築学会計画系論文報告集, 第 389 号, pp.28-36, 1988.7

14）清田忠志，清田誠良：夏季の広島市広域圈における海陸風が気温に及ぼす 影響に関する研究，日本建築学会環境系論文集，第 587 号，pp.45-51， 2005.1

15）名古屋市緑政土木局堀川総合整備室：堀川のあらまし，2000

（2008年 4 月24日原稿受理，2008年 9 月 3 日採用決定） 